\title{
Management of diarrhea-related hypernatremic dehydration
}

\author{
Rashmi Ranjan Das
}

Received: 6 January 2012 / Accepted: 4 February 2012 / Published online: 16 February 2012

(C) Springer-Verlag 2012

\section{Dear Editor,}

El-Bayoumi et al. [1] found that NS is a safe rehydration fluid, and large initial volume expansion (IVE) may be associated with increased mortality, in children with diarrhea-related hypernatremic dehydration. There are few points that need comment.

The steps of correcting hypernatremic dehydration are described elsewhere [2]. The rate of decrease of serum sodium is roughly related to the "free water" delivery (e. g., normal saline (NS) contains no free water, $1 / 2 \mathrm{NS}$ is $50 \%$ free water). Most patients with hypernatremic dehydration need concentration between $1 / 4$ to $1 / 2 \mathrm{NS}$, fluid rate of 20 $50 \%$ greater than maintenance, and time period for correction over 24-84 h [2]. This prevents excessive delivery of free water and too rapid a decrease in the serum sodium [5]. NS is most appropriate for isonatremic or hyponatremic dehydration, and hypotonic fluids for hypernatremic dehydration (as the kidney may not be able to generate enough free water to correct hypernatremia, NS is not appropriate in the latter) [3, 4].

In the Methods section, the authors describe that patients with moderate to severe dehydration (expected deficit of 5$10 \%$ or $50-100 \mathrm{ml} / \mathrm{kg}$ ) were recruited, but the amount of deficit therapy ranged from 25 to $50 \mathrm{ml} / \mathrm{kg} /$ day. This is not in accordance with the latest WHO guidelines [6]. So, the degree of dehydration might have been underassessed, and giving $\geq 40 \mathrm{ml} / \mathrm{kg}$ for IVE (rather than giving slowly) might have caused the rapid fall of sodium and increased mortality in those patients. This is also supported by the fact that the three patients that succumbed were $\leq 1$ year of age, and the guideline for correction of severe dehydration is to give the IVE over $1 \mathrm{~h}$ (not over $20 \mathrm{~min}$ as in the present study) [6].

To conclude, an understanding of the above factors will help guide fluid management in children with hypernatremic dehydration.

Conflict of interest None.

\section{References}

1. El-Bayoumi MA, Abdelkader AM, El-Assmy MM, Alwakeel AA, El-Tahan HM (2012) Normal saline is a safe initial rehydration fluid in children with diarrhea-related hypernatremia. Eur J Pediatr 171:383-388

2. Greenbaum LA (2011) Deficit therapy. In: Kliegman R, Stanton B, St. Geme J, Schor N, Behrman R (eds) Nelson textbook of pediatrics, 19th edn. Elsevier Saunders, Philadelphia

3. Moritz ML, Ayus JC (2002) Disorders of water metabolism in children: hyponatremia and hypernatremia. Pediatr Rev 23:371-380

4. Moritz ML, Ayus JC (2010) Improving intravenous fluid therapy in children with gastroenteritis. Pediatr Nephrol 25:1383-1384

5. Moritz ML, Ayus JC (2011) Intravenous fluid management for the acutely ill child. Curr Opin Pediatr 23:186-193

6. WHO (2005) The treatment of diarrhoea. A manual for physicians and other senior health workers. World Health Organization. WHO/ $\mathrm{CAH} / 03.7$ 10/03

R. R. Das $(\bowtie)$

Department of Pediatrics,

All India Institute of Medical Sciences (AIIMS),

New Delhi 110029, India

e-mail: dr_rashmipgi@yahoo.com 